\title{
KAJIAN TEORITIK TERHADAP URGENSI ASAS DALAM AKAD (KONTRAK) SYARIAH
}

\author{
Siti Zafilah Firdausiah \\ Universitas Islam Negeri Sunan Kalijaga Yogyakarta \\ sitizafilah@gmail.com
}

\begin{abstract}
The concept of or in sharia transactions is an important element that regulates and determines the relationship between the economic actors (among others) in a transaction that is related to the contract. Sharia sees the validity of the Akad can be said to be fulfilled if it meets the conditions and pillars of contract. Then, there is a basic principle that can stimulate the contract which is the basis of a foundation, basic, point of decline and footing that serves as a corridor in the creation of the contract as well as a corridor to interpret in resolving treaty disputes. Therefore, the principle becomes very important to be further examined in order to understand the various kinds of akad to make the development of contemporary business Akad and become a reference in making contract. This type of research uses library research. There are principles underlying the creation, enforcement and implementation of sharia contracts that include the principle of ibahah, the principle of freedom of law, the principle of consensualism, the principle of promise binding, the principle of balance, the principle of benefit, the principle of trust, the principle of justice, the principle of personnel, and the written principle.
\end{abstract}

Keywords: urgency, principle, sharia, contract

\begin{abstract}
Abstrak
Konsep bermuamalah atau dalam transaksi syariah terdapat unsur penting yang mengatur dan menentukan hubungan antara pelaku ekonomi (antar pihak satu dengan pihak lainnya) dalam sebuah transaksi yaitu terkait akad (kontrak). Syariah memandang keabsahan akad dapat dikatakan terlaksana jika memenuhi syarat dan rukun akad. Kemudian, terdapat asas asas yang dapat menjiwai akad yang mana asas dijadikan suatu pondasi, dasar, titik tolak dan pijakan yang berfungsi sebagai koridor dalam pembuatan akad serta sebagai koridor untuk menafsirkan dalam menyelesaikan sengketa perjanjian. Oleh karenanya, asas menjadi sangat penting untuk dikaji lebih dalam lagi guna untuk memahami macam akad dalam rangka menyeimbangi semakin berkembangnya akad-akad bisnis kontemporer dan menjadi acuan dalam pembuatan akad (kontrak). Jenis penelitian ini menggunakan kepustakaan (library research). Terdapat asas-asas yang melandasi pembuatan, penegakan dan pelaksanaan kontrak syariah yaitu meliputi asas ibahah, asas kebebasan berakad, asas konsensualisme, asas janji itu mengikat, asas keseimbangan, asas kemaslahatan, asas amanah, asas keadilan, asas personalia, dan asas tertulis.
\end{abstract}


Kata Kunci: urgensi, asas, akad (kontrak), syariah

\section{Pendahuluan}

Perkembangan ekonomi syariah saat ini sangat pesat dalam hal secara teoritis maupun praktek yang kita lihat di Indonesia, telah menjadi tolak ukur keberhasilan eksistensi ekonomi syariah. ${ }^{1}$ Oleh karenanya, dalam merespon berbagai perkembangan perekonomian syariah yang begitu pesat, tentunya dibutuhkan konsep dan prinsip bermualah yang dalam implementasinya menerapkan prinsip syariah. Prinsip atau dasar itulah yang nantinya akan membuat segala bentuk muamalah yang dilakukan bisa berjalan sesuai dengan syariat yang ada. Sehingga tercipta keseimbangan yang mampu memberikan manfaat bagi pihak pihak yang yang melakukan transaksi syariah. ${ }^{2}$

Kaitannya dengan prinsip atau dasar bagi pihak-pihak yang melakukan transaksi syariah dalam hal ini adalah pentingnya asas dalam akad (kontrak) syariah yang mana asas merupakan pondasi, acuan, tumpuan berfikir yang melandasi pembuatan, penegakan, dan pelaksanaan dalam hukum kontrak syariah. sehingga dengan adanya asas-asas dalam kontrak syariah akan membantu berbagai bentuk muamalah sesuai dengan syariah yang ada, memberi keseimbangan dan manfaat bagi pihak-pihak yang melakukan akad. Berangkat dari kerangka tersebut di atas, penuli ingin mengkaji lebih dalam lagi terkait urgensi atau pentingnya asas-asas dalam akad (kontrak) syariah guna untuk menjadi acuan bagi para pelaku ekonomi dalam melakukan transaksi syariah.

\section{Metode}

Metode penelitian yang digunakan oleh penulis adalah pustaka (library research). Riset pustaka memanfaatkan sumber perpustakaan untuk memperoleh data penelitian, membatasi kegiatannya hanya pada bahan-bahan koleksi

1 Muhammad Ardi, "Asas-Asas Perjanjian (Akad), Hukum Kontrak Syariah Dalam Penerapan Salam dan Istisna,” Jurnal Hukum Diktum, Vol. 14:2 (Februari 2016), hlm. 265.

${ }^{2}$ Dahrul Muftadin, "Dasar-Dasar Hukum Perjanjian Syariah dan Penerapannya Dalam Transaksi Syariah,” Jurnal Al- 'Adl Vol.II No.I (Januari 2018), hlm. 101. 
perpustakaan tanpa melakukan riset lapangan. ${ }^{3}$ Dalam hal ini penulis memperoleh sumber literature melalui kepustakaan seperti buku-buku, jurnal, dan ensiklopedi yang berkaitan dengan tema yang di kaji. Penelitian ini dioerientasikan membahas tentang urgensi atau pentingnya asas dalam akad (kontrak) syariah, sehingga penulis mencari dan memperoleh data serta literatur dari berbagai sumber baik jurnal, buku-buku, kamus dan yang lainnya yang berhubungan dengan asas-asas dalam akad (kontrak) syariah.

\section{Hasil}

\section{Pengertian Asas-Asas Akad Dalam Akad (Kontrak) Syariah}

Istilah asas berasal dari bahasa arab (اساس) yang berarti dasar atau landasan. Sedangkan secara terminologi, yang dimaksud dengan asas ialah nilainilai dasar (al-qiyam al-asasiyah) yang menjadi bahan pertimbangan untuk melakukan perbuatan. Karena nilai-nilai dasar itu sangat berpengaruh terhadap perbuatan atau perilaku manusia secara lahiriyah (akhlaq), maka nilai-nilai dasar tersebut harus mengandung unsur-unsur kebenaran hakiki. Rumusan asas-asas dalam hukum kontrak syariah bersumber dari Al-Qur'an dan Sunnah. Upaya ini dimaksudkan agar asas-asas yang dijadikan sebagai dasar hukum penyusunan kontrak mengandung kebenaran yang bersumber dari Allah. ${ }^{4}$

Asas berarti dasar, basis, dan fondasi. Secara terminologi, asas adalah dasar atau sesuatu yang menjadi tumpuan berpikir atau berpendapat. Istilah lain yang memiliki arti sama dengan kata asas adalah prinsip, yaitu dasar atau kebenaran yang menjadi pokok dasar berpikir, bertindak, dan sebagainya. ${ }^{5}$ Menurut Syamsul Anwar:

Asas adalah pijakan, titik tolak yang berfungsi sebagai koridor dalam pembuatan kontrak serta sebagai koridor untuk menafsirkan dalam menyelesaikan sengketa perjanjian. Asas juga bisa dikatakan sebagai

\footnotetext{
${ }^{3}$ Mestika Zed, Metode Penelitian Kepustakaan (Jakarta: Yayasan Obor Indonesia, 2004), hlm. 1-2.

${ }^{4}$ Burhanuddin S, Hukum Kontrak Syariah, (Yogyakarta: BPFE, 2009), hlm. 41-42.

${ }^{5}$ Gemala Dewi, Hukum Perikatan Islam di Indonesia (Jakarta: Kencana, 2006), hlm. 30.
} 
pedoman, landasan, serta pikiran dasar yang bersifat umum yang melandasi aturan hukum. ${ }^{6}$

Asas adalah nilai-nilai dasar yang berpengaruh terhadap perbuatan. Karena nilai-nilai dasar itu berpengaruh terhadap perbuatan dan prilaku manusia secara lahiriyah (akhlak), maka nilai-nilai dasar tersebut harus mengandung unsur-unsur kebenaran hakiki. Dan dalam pandangan Islam, untuk mendapatkan kebenaran yang hakiki sumbernya adalah akidah dan syariah. Dengan menjadikan akidah dan syariah sebagai sumber kebenaran suatu landasan kontrak (asas), maka diharapkan akan dipertanggungjawabkan dihadapan Allah SWT. ${ }^{7}$

Apabila asas dikaitkan dengan hukum maka kebenaran yang dipergunakan adalah sebagai tumpuan berfikir dan alasan pendapat terutama dalam penegakan dan pelaksanaan hukum. Apabila dikaitkan dengan dengan perjanjian dalam hukum kontrak syariah adalah, kebenaran yang dipergunakan sebagai tumpuan berpikir dan alasan pendapat tentang perjanjian terutama dalam penegakan dan pelaksanaan hukum kontrak syariah. ${ }^{8}$

Kontrak dalam Islam disebut dengan "akad” yang berasal dari bahasa Arab "al-Aqd" yang berati perikatan, perjanjian, kontrak, atau permufakatan (alittifaq), dan transaksi. Menurut Dictionary of Business Term "aqd or Contract is Transaction involing two or more individuals whereby each becomes obligated to the other, with reciprocal rights to demandperformance of what is promised" (akad adalah sebuah persetujuan yang mengikat secara hukum antara dua pihak atau lebih yang sama, untuk pertimbangan, satu atau lebih pihak setuju untuk melakukan sesuatu). ${ }^{9}$

Akad merupakan keterkaitan atau pertemuan ijab dan kabul yang berakibat timbulnya akibat hukum. Akad merupakan tindakan hukum dua pihak karena

${ }^{6}$ Ceramah yang disampaikan dalam pertemuan kelas mata kuliah Hukum Kontrak Bisnis Syariah di

UIN Sunan Kaljaga Yogyakarta, tanggal 18 Oktober 2019.

7 Muhammad Ardi, “Asas-Asas Perjanjian (Akad), Hukum Kontrak Syariah Dalam Penerapan

Salam dan Istisna," Jurnal Hukum Diktum, Vol. 14:2 (Februari 2016), hlm. 266.

${ }^{8}$ Mohammad Daud Ali, Hukum Islam: Pengantar Ilmu Hukum dan Tata Hukum Islam di Indonesia (Jakarta: RajaGrafindo Persada. 2000), hlm. 114.

${ }^{9}$ Abdul Manan, Hukum Ekonomi Syariah (Jakarta: Kencana. 2014), hlm. 72. 
akad adalah pertemuan ijab yang merepresentasikan kehendak dari satu pihak dan kabul yang menyatakan kehendak pihak lain. Tujuan akad adalah untuk melahirkan suatu akibat hukum. Lebih tegas lagi tujuan akad adalah maksud bersama yang dituju dan yang hendak diwujudkan oleh para pihak melalui pembuatan akad. ${ }^{10}$

Dengan demikian asas akad (kontrak) syariah adalah landasan yang melatarbelakangi dalam pembentukan,penegakan dan pelaksanaan kontrak syariah untuk mendapatkan manfaat dan maslahah bagi para pihak yang mengikatkan diri dalam suatu perjanjian.

\section{Fungsi dan Peranan Asas}

Dalam hal aturan-aturan hukum yang tidak dapat menetapkan mengenai hukum sesuatu atau memecahkan persoalan, akan dibutuhkan bantuan asas-asas hukum untuk memberikan makna terhadap aturan-aturan hukum yang sudah ada. Setiap kasus (hukum) harus dipecahkan dengan melakukan penafsiran sebagai semacam pelengkap. Di sinilah menafsirkan aturan hukum itu bukanlah berarti menafsirkan aturan dalam arti conversational interpretation, melainkan suatu constructive interpretation.

Fungsi asas-asa hukum yaitu: pertama, asas-asas hukum memberikan keterjalinan dan aturan-aturan hukum yang tersebar. Kedua, asas-asas hukum dapat difungsikan untuk mencari pemecahan atas masalah-masalah baru yang muncul dan membuka bidang-bidang liputan masalah baru. Asas-asas hukum juga menjustifikasikan prinsip-prinsip "etika", yang merupakan substansi dari aturanaturan hukum. Ketiga, yakni asas-asas hukum dalam hal demikian dapat digunakan untuk "menulis ulang" bahan-bahan ajaran hukum yang ada sedemikian rupa, sehingga dapat dimunculkan solusi terhadap persoalan-persoalan baru yang berkembang.

Asas-asas hukum bertujuan untuk memberikan arahan yang layak atau pantas (menurut hukum: rechtimatig) dalam hal menggunakan atau menerapkan

${ }_{10}$ Syamsul Anwar, Hukum Perjanjian Syariah: Studi tentang Teori Akad dalam Fikih Muamalat

(Jakarta: PT RajaGrafindo Persada, 2007), hlm. 68-69. 
aturan-aturan hukum. Asas-asas hukum tersebut berfungsi sebagi pedoman atau arahan orientasi agar suatu hukum dapat dan boleh dijalankan. Asas-asas hukum tersebut tidak hanya akan berguna sebagai pedoman ketika menghadapi kasuskasus sulit, tetapi juga pada umumnya berguna dalam hal menerapkan aturan. Asas-asas hukum membentuk konteks interpretasi yang niscaya dari aturan-aturan hukum. Mengenai fungsi interpretatif tersebut, asas-asas hukum demi kepentingan aturan-aturan hukum mensyaratkan pelibatan moral dan susila. Meskipun aturanaturan (hukum) harus diterangkan beranjak dari latar belakang asas-asas hukum niscaya terkonkretisasi ke dalam aturan-aturan, satu persoalan lagi yang perlu dijelaskan, yakni bagaimana keberadaan asas-asas hukum dalam kaitannya dengan hukum positif. ${ }^{11}$

\section{Asas-Asas Akad Dalam Hukum Syariah}

\section{Asas Ibahah (Mabda' al-Ibahah)}

Asas ibahah adalah asas umum hukum Islam dalam bidang muamalat secara umum. Asas ini dirumuskan dalam adagium

$$
\text { الاصل في الشروط في المعاملات الحل والابباحة الا بدليل }
$$

"Pada asasnya segala sesuatu itu boleh dilakukan sampai ada dalil yang melarangnya."

Asas ini merupakan kebalikan dari asas yang berlaku dalam masalah ibadah. Dalam hukum Islam, untuk tindakan-tindakan ibadah berlaku asas bahwa bentuk-bentuk ibadah yang sah adalah bentuk-bentuk yang disebutkan dalam dalil-dalil syariah. orang tidak dapat membuat-buat bentuk baru ibadah yang tidak pernah ditentukan oleh Nabi Saw. Bentuk-bentuk baru ibadah yang dibuat tanpa pernah diajarkan oleh Nabi Saw itu disebut bidah dan tidak sah hukumnya. Sebaliknya, dalam tindakan-tindakan muamalat berlaku asas sebaliknya, yaitu bahwa segala sesuatu itu sah dilakukan sepanjang tidak ada larangan tegas atas tindakan itu. Bila dikaitkan dengan tindakan hukum, khususnya perjanjian, maka

\footnotetext{
${ }^{11}$ Yasardin, Asas Kebebasan Berkontrak Syariah (Jakarta:Kencana, 2018), hlm. 82.
} 
ini berarti bahwa tindakan hukum dan perjanjian apa pun dapat dibuat sejauh tidak ada larangan khusus mengenai perjanjian tersebut. ${ }^{12}$

Selain itu, hal ini berarti bahwa Islam memberi kesempatan luas kepada yang berkepentingan untuk mengembangkan bentuk dan macam transaksi baru sesuai dengan perkembangna zaman dan kebutuhan masyarakat. ${ }^{13}$

\section{Asas Kebebasan Berakad (Mabda' Hurriyah at-Ta'aqud)}

Asas kebebasan ini menjadi prinsip dasar dalam hukum Islam. Kebebasan ini berarti kemerdekaan secara umum, baik kebebasan individual maupun komunal. ${ }^{14}$ Asas ini merupakan prinsip dasar pula dari akad atau hukum perjanjian. Pihak-pihak yang melakukan akad mempunyai kebebasan untuk membuat perjanjian, baik dari segi materi atau isi yang diperjanjikan, menentukan pelaksanaan dan persyaratan-persyaratan lainnya, melakukan perjanjian dengan siapa pun, maupun bentuk perjanjian (tertulis atau lisan) termasuk menetapkan cara-cara penyelesaian bila terjadi sengketa. Kebebasan membuat perjanjian ini dibenarkan selama tidak bertentangan dengan ketentuan syariah Islam. ${ }^{15}$

Dengan kata lain, syariah Islam memberikan kebebasan kepada setiap orang yang melakukan akad sesuai yang diinginkan, tetapi yang menentukan akibat hukumnya adalah ajaran agama. Tujuan untuk menjaga agar tidak terjadi penganiayaan antara sesama manusia melalui akad dan syarat-syarat yang dibuatnya. Asas ini pula menghindari semua bentuk paksaan, tekanan, dan penipuan dari pihak manapun. Perbuatan-perbuatan tersebut merupakan bagian ketertiban umum, sehingga apabila dilanggar maka termasuk melanggar ketentuan umum dan/atau kesusilaan. Adanya unsur pemaksaan dan pemasungan kebebasan

\footnotetext{
12 Syamsul Anwar, Hukum Perjanjian Syariah: Studi tentang Teori Akad dalam Fikih Muamalat, hlm. 83-84.

${ }^{13}$ Aunur Rohim Faqih, Bank Syariah, Kontrak Bisnis Syariah, \& Penyelesaian Sengketa di Pengadilan (Yogyakarta: FH UII Press, 2017), hlm. 151.

${ }^{14}$ Yasardin, Asas Kebebasan Berkontrak Syariah, hlm. 87.

15 Fathurrahman Djamil, Penerapan Hukum Perjanjian dalam Transaksi di Lembaga Keuangan Syariah (Jakarta: Sinar Grafika, 2012), hlm. 14.
} 
bagi pihak-pihak yang melakukan perjanjian, maka legalitas perjanjian yang dilakukan bisa dianggap meragukan bahkan tidak sah. ${ }^{16}$

Adanya asas kebebasan berakad dalam hukum Islam didasarkan kepada beberapa dalil antara lain adalah:

a. Firman Allah

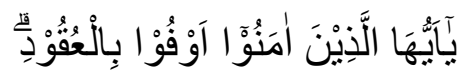

"Wahai orang-orang beriman, penuhilah akad-akad (perjanjian-perjanjian)" [QS. 5. 1].

b. Sabda Nabi Saw., "Orang-orang Muslim itu senantiasa setia kepada syaratsyarat (janji-janji) mereka."

c. Sabda Nabi Saw., "Barang siapa menjual pohon kurma yang sudah dikawinkan, maka buahnya adalah untuk penjual (tidak ikut terjual), kecuali apabila pembeli mensyaratkan lain."

d. Kaidah hukum Islam, Pada asasnya akad itu adalah kesepakatan para pihak dan akibat hukumnya adalah apa yang mereka terapkan atas diri nereka melalui janji.

Kebebasan membuat akad dalam hukum Islam tidaklah mutlak, melainkan dibatasi. Dalam hukum Islam, pembatasan itu dikaitkan dengan "larangan makan harta sesama dengan jalan batil" sebagaimana dinyatakan dalam QS. 4: 29.

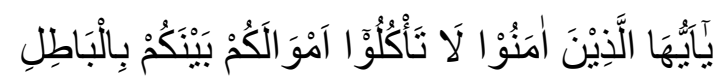

"Hai orang-orang yang beriman, janganlah kamu saling memakan harta sesamamu dengan jalan yang batil”

Yang dimaksud dengan makan harta sesama dengan jalan batil adalah makan harta orang lain dengan cara yang tidak dibenarkan dan tidak sah menurut hukum Syariah, baik yang dilarang secara langsung di dalam nas maupun berdasarkan ijtihad atas nas. Secara umum, dapat dikatakan bahwa makan harta dengan jalan batil adalah bertentangan dengan ketertiban umum dan kesusilaan. Hanya saja, ketertiban umum dan kesusilaan dalam hukum Islam lebih luas

\footnotetext{
${ }^{16}$ Ibid, hlm. 15.
} 
cakupannya, karena mencakup larangan riba, garar dan syarat penyerta akad yang fasid. $^{17}$

Pengertian asas kebebasan berkontrak dalam Islam berbeda dengan apa yang dimaksud dengan kebebasan berkontrak dalam hukum konvensional. Perbedaannya bahwa kebebasan dalam berkontrak dalam Islam ialah kebebasan yang bersifat terikat dengan hukum syara'. Karena bersifat terikat maka kebebasan berkontrak itu akan dibenarkan selama syarat-syarat yang dikemukakan tidak bertentangan dengan ketentuan prinsip-prinsip syariah. ${ }^{18}$

\section{Asas Konsensualisme (Mabda' ar-Radha'iyyah)}

Asas ridhaiyyah ini dalam KUH Perdata sering dinamakan asas konsensualisme atau asas konsensuil. Asas ini termuat dalam Pasal $1320 \mathrm{KUH}$ Perdata mengenai syarat sahnya perjanjian, dan merupakan penjabaran lebih lebih lanjut dari asas kebebasan berkontrak. Asas konsensualisme menganut paham bahwa perjanjian lahir pada saat tercapai kesepakatan para pihak. Dengan perkataan lain, perjanjian itu sudah sah apabila tercapai sepakat (consensus) mengenai hal-hal yang pokok dan tidaklah diperlukan sesuatu formalitas. ${ }^{19}$

Segala transaksi yang dilakukan harus berdasarkan keridhaan diantara masing-maisng pihak. ${ }^{20}$ Asas ini menyatakan bahwa semua kontrak yang dilakukan oleh para pihak harus didasarkan kepada kerelaan semua pihak yang membuatnya. Kerelaan para pihak yang berkontrak adalah jiwa setiap kontrak yang islami dan dianggap sebagai syarat terwujudnya semua transaksi. Jika dalam suatu kontrak asas ini tidak terpenuhi, maka kontrak yang dibuatnya telah dilakukan dengan cara yang batil (al-akl bil bathil). Kontrak yang dilakukan itu tidak dapat dikatakan telah mencapai sebuah bentuk usaha yang dilandasi saling rela antara pelakunya jika di dalamnya terdapat unsur tekanan, paksaan, penipuan, atau ketidakjujuran dalam pernyataan.

\footnotetext{
${ }^{17}$ Syamsul Anwar, Hukum Perjanjian Syariah, hlm. 87.

${ }^{18}$ Burhanuddin S, Hukum Kontrak Syariah, hlm. 42.

${ }^{19}$ Fathurrahman Djamil, Penerapan Hukum Perjanjian dalam Transaksi di Lembaga Keuangan Syariah, hlm. 23.

${ }^{20}$ Burhanuddin, Hukum Kontrak Syariah, hlm. 45.
} 
Kerelaan (ridha al-taradhi) adalah sikap batin yang abstrak (amr kahfiy). Untuk menunjukkan bahwa dalam sebuah kontrak kerelaan telah dicapai, diperukan indikator yang merefleksikannya. Indikator dimaksud adalah formulasi (shigot) ijab qabul. Oleh karena itu, formulasi ijab qabul harus dibuat dengan jelas dan perinci sedemikian rupa sehingga dapat menerjemahkan secara memadai bahwa para pihak dipastikan telah mencapai kondisi kerelaan ketika kontrak dilakukan.

Hukum Islam mempunyai pandangan yang berbeda dengan hukum perdata umum dalam hal kerelaan dalam membuat kontrak. Dalam hukum perdata umum, kontrak dianggap sah apabila dibuat atas dasar sukarela, meskipun tidak memerhatikan nilai-nilai agama. Adapun dalam hukum Islam, nila-nilai agama sangat diperhatikan. Oleh karena itu, kemerdekaan seseorang dalam membuat kontrak tidak boleh menyimpang dari ketentuan agama Islam, meskipun orang yang membuat kontrak itu telah menyatakan kerelaannya. Dengan kata lain, hukum Islam pada dasarnya memberi kebebasan orang yang membuat kontrak sesuai dengan keinginannya, tetapi yang menentukan akibat hukumnya adalah ajaran agama, untuk menjaga jangan sampai terjadi penganiayaan antara sesama manusia melalui kontrak yang dibuatnya. ${ }^{21}$

Dasar asas ini adalah kalimat antaradhim minkum ${ }^{22}$ (saling rela di antara kalian) sebagaimana terdapat dalam Alqur'an An-Nisa' (4): 29:

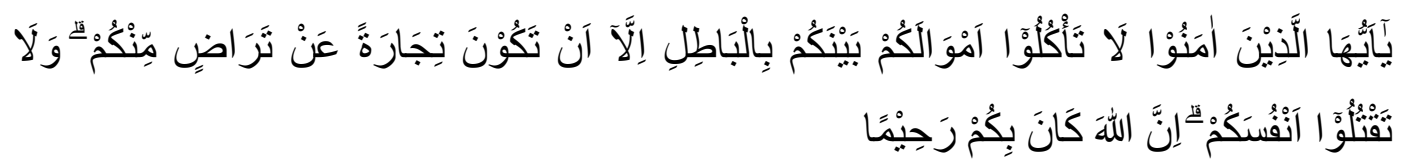

Hai orang-orang yang beriman, janganlah kamu saling memakan harta sesamamu dengan jalan yang batil, kecuali dengan jalan perniagaan yang Berlaku dengan suka sama-suka di antara kamu. dan janganlah kamu membunuh dirimu. Sesungguhnya Allah adalah Maha Penyayang kepadamu.

${ }^{21}$ Abdul Manan, Hukum Ekonomi Syariah, hlm. 79-80.

${ }^{22}$ Fathurrahman Djamil, Penerapan Hukum Perjanjian dalam Transaksi di Lembaga Keuangan

Syariah, hlm. 22. 


\section{Asas Janji itu Mengikat}

Dalam Alquran dan Hadis terdapat banyak perintah agar memenuhi janji. Dalam kaidah ushul fikih, "perintah itu pada asasnya menunjukkan wajib". Ini berarti bahwa janji itu mengikat dan wajib dipenuhi. Di antara ayat dan hadis dimaksud adalah:

a. Firman Allah

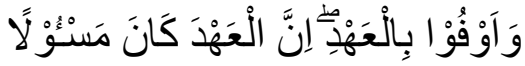

“...dan penuhilah janji, sesungguhnya janji itu akan dimintakan pertanggungjawabannya" (QS. 17: 34).

b. Asar dari Ibn Mas'ud, Janji itu adalah utang. ${ }^{23}$

Asas ini berasal dari hadis Nabi Muhammad saw yang artinya; "Orangorang muslim itu terikat kepada perjanjian-perjanjian (klausul-klausul) mereka, kecuali perjanjian (klausul) yang mengharamkan yang halal atau menghalalkan yang haram". Dari hadis di atas dapat dipahami bahwa setiap orang yang melakukan perjanjian terikat kepada isi perjanjian yang telah disepakati bersama pihak lain dalam perjanjian. Sehingga seluruh isi perjanjian adalah sebagai peraturan yang wajib dilakukan oleh para pihak yang mengikatkan diri dalam perjanjian. $^{24}$

\section{Asas Keseimbangan (Mabda' at-Tawazun fi al-Mu'awadhah)}

Asas keseimbangan para pihak dalam perjanjian sering dinamakan juga asas persamaan atau kesetaraan. Sebagaimana asas equality before the law, maka kedudukan para pihak dalam perjanjian adalah seimbang (equal). Meskipun demikian, secara faktual terdapat keadaan di mana salah satu pihak memiliki kedudukan yang lebih tinggi dibanding pihak lainnya, seperti hubungan pemberi fasilitas dengan penerima fasilitas, adanya perjanjian baku (standard contract)

${ }^{23}$ Syamsul Anwar, Hukum Perjanjian Syariah, hlm. 89-90.

${ }^{24}$ Ubaidullah Muayyad, "Asas-Asas Perjanjian Dalam Hukum Perjanjian Islam”, “Anil Islam Vol.8 Nomor 1, Juni 2015 hlm. 20 
yang memaksa pihak lain seolah-olah tidak memiliki pilihan selain take it or leave it. $^{25}$

Meskipun secara faktual masing-masing pihak yang akan mengadakan kontrak memiliki berbagai latar belakang yang berbeda, namun dalam hukum Islam tetap menekankan perlunya berpegang pada asas kesetimbangan. Karena asas kesetimbangan dalam akad terkait dengan pembagian hak dan kewajiban. Misalnya adanya hak mendapatkan keuntungan dalam investasi, berati harus disertai dengan kewajiban mengandung resiko. Ketentuan ini merujuk pada kaidah fiqh yang menyatakan: (الغنم بالغرم) "keuntungan muncul bersama risiko" dan (الخراج بالضمان ) "hasil usaha muncul bersama tanggungan yang dikeluarkan." 26

Asas ini memberikan landasan bahwa kedua yang melakukan perjanjian mempunyai kedudukan yang sama antara satu dan lainnya. ${ }^{27}$ Dasar hukum dari asas ini adalah QS. Al-Hujurat (49): 13:

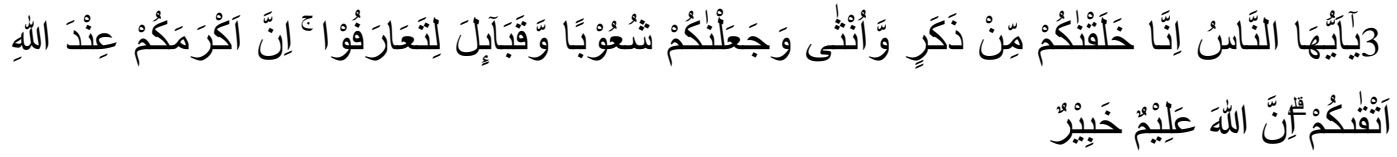

Hai manusia, Sesungguhnya Kami menciptakan kamu dari seorang laki-laki dan seorang perempuan dan menjadikan kamu berbangsa - bangsa dan bersuku-suku supaya kamu saling kenal-mengenal. Sesungguhnya orang yang paling mulia diantara kamu disisi Allah ialah orang yang paling taqwa diantara kamu. Sesungguhnya Allah Maha mengetahui lagi Maha Mengenal.(QS. Al-Hujurat (49): 13).

\section{Asas Kemaslahatan (Tidak Memberatkan)}

Dengan asas kemaslahatan dimaksudkan bahwa akad yang dibuat oleh para pihak bertujuan untuk mewujudkan kemaslahatan bagi mereka yang tidak boleh menimbulkan kerugian (mudharat), atau keadaan memberatkan

${ }^{25}$ Fathurrahman Djamil, Penerapan Hukum Perjanjian dalam Transaksi di Lembaga Keuangan Syariah, hlm. 19.

${ }^{26}$ Burhanuddin S, Hukum Kontrak Syariah, hlm. 43.

27 Fathurrahman Djamil, Penerapan Hukum Perjanjian dalam Transaksi di Lembaga Keuangan

Syariah, hlm, 19. 
(masyaqqah). Asas kemaslahatan atau asas kemanfaatan ini antara lain berkenaan dengan objek akad. Tidak semua objek dalam pandangan Islam dapat dijadikan objek akad. Islam mengharamkan akad yang berkaiatan dengan hal-hal yang bersifat mudharat atau mafsadat, seperti jual beli benda-benda yang tidak bermanfaat apalagi membahayakan. Dengan kata lain, barang atau usaha yang menjadi objek akad dibenarkan (halal) dan baik (thayyib). Dasar dari objek yang bermanfaaat antara lain ${ }^{28}$ :

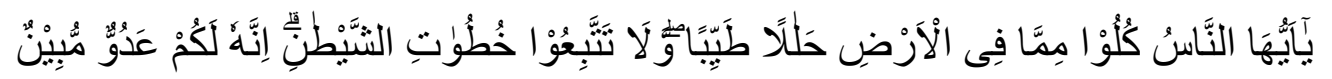

Hai sekalian manusia, makanlah yang halal lagi baik dari apa yang terdapat di bumi, dan janganlah kamu mengikuti langkah-langkah syaitan; karena Sesungguhnya syaitan itu adalah musuh yang nyata bagimu. (QS. Al-Baqarah (2): 168).

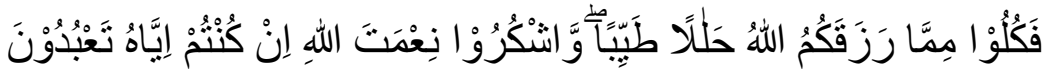

Maka makanlah yang halal lagi baik dari rezki yang telah diberikan Allah kepadamu; dan syukurilah nikmat Allah, jika kamu hanya kepada-Nya saja menyembah. (QS. An-Nahl (16): 114).

Pada hakekatnya, tujuan mengadakan akad ialah untuk mencapai kemaslahatan bagi masing-masing pihak. Pengertian maslahat dalam Islam meliputi dimensi kehidupan dunia dan akhirat. Dan untuk menjamin tercapainya kemaslahatan maka kaidah fiqh yang berlaku:

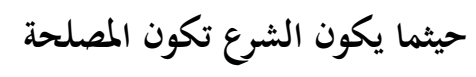

“apabila hukum syara’ dilaksanakan, maka pastilah tercipta kemaslahatan"29

${ }^{28}$ Fathurrahman Djamil, Penerapan Hukum Perjanjian dalam Transaksi di Lembaga Keuangan

Syariah, hlm, 19.

${ }^{29}$ Burhanudin S, Hukum Kontrak Syariah, hlm. 44. 


\section{Asas Amanah}

Asas amanah merupakan bentuk kepercayaan yang timbul karena adanya iktikad baik dari masing-masing pihak untuk mengadakan akad. Dalam hukum kontrak syariah, terdapat bentuk akad yang bersifat amanah. ${ }^{30}$

Dengan asas amanah dimaksudkan bahwa masing-masing pihak haruslah beriktikad baik dalam bertransaksi dengan pihak lainnya dan tidak dibenarkan salah satu pihak mengekploitasi ketidaktahuan mitranya. Dalam kehidupan masa kini banyak sekali objek transaksi yang dihasilkan oleh satu pihak melalui suatu keahlian yang sangat spesialis dan profesionalisme yang tinggi sehingga ditransaksikan, pihak lain yang menjadi mitra transaksi tidak banyak mengetahui seluk beluknya. Oleh karena itu, ia sangat bergantung kepada pihak yang menguasainya. Profesi kedokteran, terutama dokter spesialis, misalnya hanya diketahui dan dikuasai oleh para dokter saja. Masyarakat umum tidak mengetahui seluk beluk profesi tersebut. Oleh karena itu, ketika seorang pasien sebagai salah satu pihak transaksi akan diterapkan suatu metode pengobatan dan penanganan penyakitnya, sang pasien sangat tergantung kepada informasi dokter untuk mengambil keputusan menjalani metode tersebut. Begitu pula terdapat barangbarang canggih, tetapi juga mungkin menimbulkan risiko berbahaya bila salah penggunaannya. Dalam hal ini, pihak yang bertransaksi dengan objek barang tersebut sangat tergantung kepada informasi produsen yang menawarkan barang tersebut. Oleh karena itu, dalam kaitan ini dalam hubungan hukum perjanjian Islam dituntut adanya sikap amanah para pihak yang menguasainya untuk memberi informasi yang sejujurnya kepada pihak lain yang tidak mengetahuinya. ${ }^{31}$

Suatu bentuk perjanjian yang disebut perjanjian amanah, salah satu pihak yang bergantung kepada informasi jujur dari pihak lainnya untuk mengambil keputusan untuk menutup perjanjian bersangkutan. Diantara ketentuannya, adalah bahwa bohong atau penyembunyian informasi yang semestinya disampaikan dapat menjadi alasan pembatalan akad bila di kemudian hari ternyata informasi itu

\footnotetext{
${ }^{30}$ Ibid, hlm. 44

${ }^{31}$ Syamsul Anwar, Hukum Perjanjian Syariah, hlm. 91.
} 
tidak benar yang telah mendorong pihak lain untuk menutup perjanjian. Contoh paling sederhana dalam hukum Islam adalah akad murabahah, yang merupakan salah satu akad amanah. Pada zaman sekarang wilayah akad amanah tidak saja hanya dibatasi pada akad seperti murabahah, tetapi juga meluas ke dalam akad takaful (asuransi) bahkan juga banyak akad yang pengetahuannya mengenai objeknya hanya dikuasai oleh satu salah satu pihak saja. ${ }^{32}$

\section{Asas Keadilan}

Keadilan adalah tujuan yang hendak diwujudkan oleh semua hukum. Dalam hukum Islam, keadilan langsung merupakan perintah Alquran yang menegaskan,

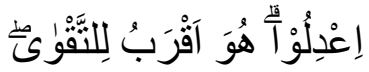

$$
\begin{aligned}
& \text { “..Berlaku adillah, karena adil itu lebih dekat kepada takwa...” [QS. 5: 8]. }
\end{aligned}
$$

Keadilan merupakan sendi detiap perjanjian yang dibuat oleh para pihak. Sering kali di zaman modern akan ditutup satu pihak dengan pihak lain tanpa ia memiliki kesempatan untuk melakukan negosiasi mengenai klausul akad tersebut, karena klausul akad itu telah dibakukan oleh pihak lain. Tidak mustahil bahwa dalam pelaksanannya akan timbul kerugian kepada pihak yang menerima syarat baku itu karena di dorong kebutuhan. Dalam hukum Islam kontemporer telah diterima suatu asas bahwa demi keadilan syarat baku itu dapat diubah oleh pengadilan apabila memang ada alasan untuk itu. ${ }^{33}$

Pelaksanaan asas ini dalam kontrak dituntut untuk berlaku benar dalam mengungkapkan kehendak dan keadaan, memenuhi perjanjian yang telah disepakati bersama dan memenuhi segala hak dan kewajiban, tidak saling menzalimi dan dilakukannya secara seimbang tanpa merugikan pihak lain yang terlibat dalam kontrak tersebut. ${ }^{34}$

\footnotetext{
${ }^{32}$ Syamsul Anwar, Hukum Perjanjian Syariah, hlm. 91.

${ }^{33}$ Ibid, hlm. 92.

${ }^{34}$ Abdul Manan, Hukum Ekonomi Syaria, hlm. 77.
} 


\section{Asas Kepribadian (Personalia)}

Asas kepribadian merupakan asas yang menentukan bahwa seseorang yang akan melakukan dan atau membuat kontrak hanya untuk kepentingan perseorangan. ${ }^{35}$ Asas ini menegaskan bahwa akibat hukum yang timbul dari suatu akad hanya berlaku bagi pihak yang membuatnya. Firman Allaah SWT dalam surat al-Baqarah (2): 286:

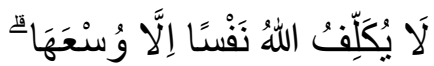

"Allah tidak membebani seseorang melainkan sesuai dengan kesanggupannya"

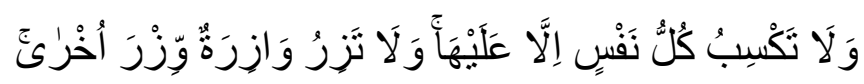

"Dan tidaklah seorang membuat dosa melainkan kemudharatannya kembali kepada dirinya sendiri; dan seorang yang berdosa tidak akan memikul dosa orang lain". 36

Selain dari asas-asas yang telah dipaparkan di atas, terdapat pula asas tertulis. Suatu perjanjian hendaknya dilakukan seca ra tertulis agar dapat dijadikan sebagai alat bukti apabila di kemudian hari terjadi persengketaan. Sebagaimana yang disebutkan dalam surat al-Baqarah ayat 282-283

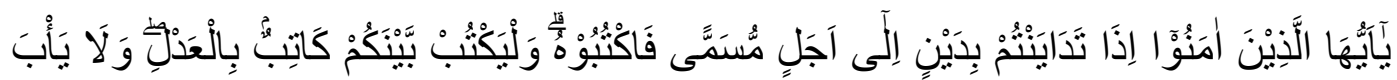

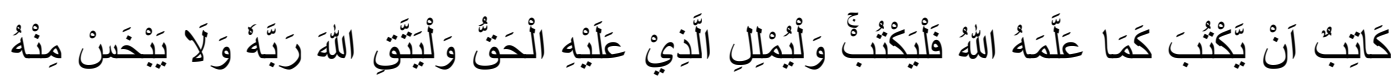

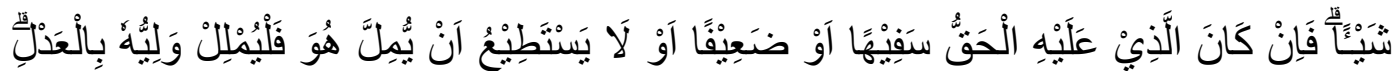

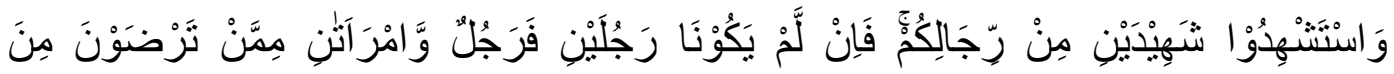

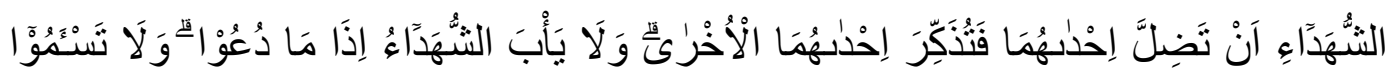

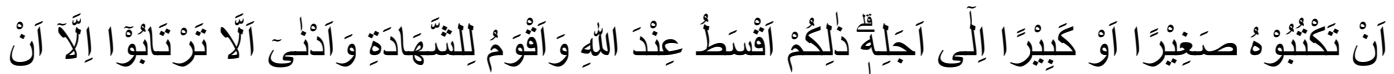

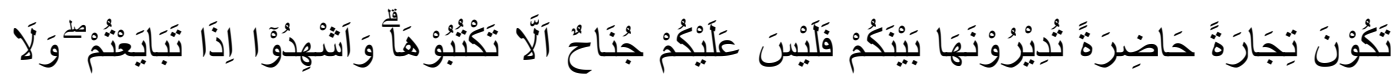

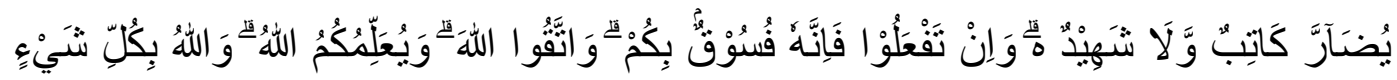

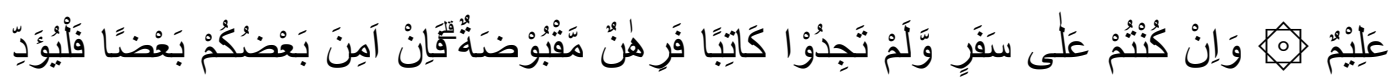

\footnotetext{
${ }^{35}$ Akhmad Hulaify, “Asas-Asas Kontrak (Akad) Dalam Hukum Syariah,” hlm. 52.

${ }^{36}$ Al-An'am (6): 164.
} 


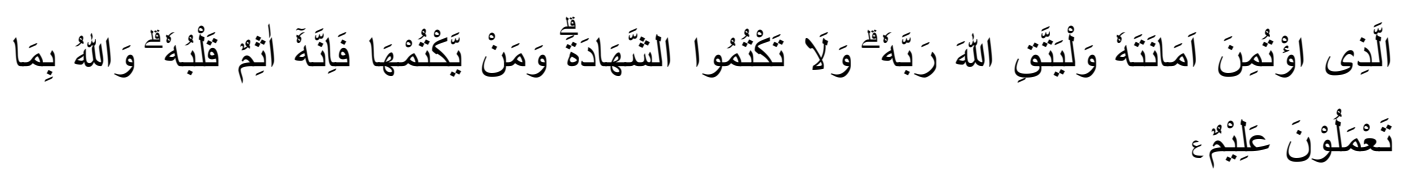

"Hai orang-orang yang beriman, apabila kamu bermu'amalah tidak secara tunai untuk waktu yang ditentukan, hendaklah kamu menuliskannya. dan hendaklah seorang penulis di antara kamu menuliskannya dengan benar. dan janganlah penulis enggan menuliskannya sebagaimana Allah mengajarkannya, meka hendaklah ia menulis, dan hendaklah orang yang berhutang itu mengimlakkan (apa yang akan ditulis itu), dan hendaklah ia bertakwa kepada Allah Tuhannya, dan janganlah ia mengurangi sedikitpun daripada hutangnya. jika yang berhutang itu orang yang lemah akalnya atau lemah (keadaannya) atau Dia sendiri tidak mampu mengimlakkan, Maka hendaklah walinya mengimlakkan dengan jujur. dan persaksikanlah dengan dua orang saksi dari orang-orang lelaki (di antaramu). jika tak ada dua oang lelaki, Maka (boleh) seorang lelaki dan dua orang perempuan dari saksi-saksi yang kamu ridhai, supaya jika seorang lupa Maka yang seorang mengingatkannya. janganlah saksi-saksi itu enggan (memberi keterangan) apabila mereka dipanggil; dan janganlah kamu jemu menulis hutang itu, baik kecil maupun besar sampai batas waktu membayarnya. yang demikian itu, lebih adil di sisi Allah dan lebih menguatkan persaksian dan lebih dekat kepada tidak (menimbulkan) keraguanmu. (Tulislah mu'amalahmu itu), kecuali jika mu'amalah itu perdagangan tunai yang kamu jalankan di antara kamu, Maka tidak ada dosa bagi kamu, (jika) kamu tidak menulisnya. dan persaksikanlah apabila kamu berjual beli; dan janganlah penulis dan saksi saling sulit menyulitkan. jika kamu lakukan (yang demikian), Maka Sesungguhnya hal itu adalah suatu kefasikan pada dirimu. dan bertakwalah kepada Allah; Allah mengajarmu; dan Allah Maha mengetahui segala sesuatu."

"jika kamu dalam perjalanan (dan bermu'amalah tidak secara tunai) sedang kamu tidak memperoleh seorang penulis, Maka hendaklah ada barang tanggungan yang dipegang (oleh yang berpiutang). akan tetapi jika sebagian kamu mempercayai sebagian yang lain, Maka hendaklah yang dipercayai itu menunaikan amanatnya (hutangnya) dan hendaklah ia bertakwa kepada Allah Tuhannya; dan janganlah kamu (para saksi) Menyembunyikan persaksian. dan Barangsiapa yang menyembunyikannya, Maka Sesungguhnya ia adalah orang yang berdosa hatinya; dan Allah Maha mengetahui apa yang kamu kerjakan"

Dapat dipahami bahwa Allah SWT menganjurkan kepada manusia agar suatu perjanjian dilakukan secara tertulis, dihadiri para saksi dan diberikan tanggung jawab individu yang melakukan perjanjian dan yang menjadi saksi 
tersebut. Selain itu dianjurkan pula jika suatu perjanjian dilaksanakan tidak secara tunai maka dapat dipegang suatu benda jaminan. ${ }^{37}$

Namun, mengenai asas tertulis (kitabah) ini terdapat perbedaan pendapat. Menurut Syamsul Anwar ${ }^{38}$, asas tertulis merupakan kebalikan dari asas konsensualisme yang cukup ada kata sepakat tanpa adanya formalitas. Menurutnya, akad adalah perjanjian tertulis itu adalah syarat teknis bukan syarat syar'i. Sedangkan pendapat yang menganjurkan adanya asas tertulis dalam perjanjian yaitu untuk menghindari jika terjadi permasalahan atau sengketa dikemudian hari.

\section{Penutup}

Asas merupakan dasar yang dijadikan tumpuan berpikir, yang melandasi aturan hukum. Sehingga jika asas dikaitkan dengan akad (kontrak) syariah maka merupakan dasar atau landasan yang melatarbelakangi dalam pembentukan, penegakan, dan pelaksanaan akad (kontrak) syariah untuk mendapatkan manfaat yang mashlahah bagi para pihak yang mengikatkan diri.

Fungsi asas adalah sebagai pedoman atau arahan orientasi agar suatu hukum dapat dan boleh dijalankan. Asas juga berfungsi sebagai koridor dalam pembuatan kontrak serta untuk menafsirkan dalam menyelesaikan sengketa perjanjian.

Asas-asas dalam hukum syariah meliputi: asas ibahah (mabda' al-ibahah), asas kebebasan berakad (mabda' hurriyah at-ta'aqud), asas konsensualisme (mabda' ar-radha 'iyyah), asas janji itu mengikat, asas keseimbangan (mabda' attawazun fi al-mu'awadhah), asas kemaslahatan (tidak memberatkan), asas amanah, asas keadilan, serta asas kepribadian (personalia). Selain itu, terdapat juga asas tertulis. Namun, mengenai asas tertulis ini ada perbedaan pendapat. Asas

\footnotetext{
${ }^{37}$ Gemala Dewi, Hukum Perikatan Islam di Indonesia, hlm. 37-38.

${ }^{38}$ Ceramah yang disampaikan dalam pertemuan kelas mata kuliah Hukum Kontrak Bisnis Syariah
}

di UIN Sunan Kaljaga Yogyakarta, tanggal 18 Oktober 2019. 
tertulis merupakan kebalikan dari asas konsensualisme yang cukup adanya kata sepakat tanpa harus ada formalitas dan adanya pernyataan perjanjian tertulis itu adalah syarat teknis bukan syarat syar'i. Sedangkan pendapat yang mengajurkan adanya asas tertulis dengan untuk menghindari permasalahan atau sengketa di kemudian hari.

\section{DAFTAR PUSTAKA}

Ali, Mohammad Daud, Hukum Islam: Pengantar Ilmu Hukum dan Tata Hukum Anwar, Syamsul, Ceramah yang disampaikan dalam pertemuan kelas mata kuliah Anwar, Syamsul, Hukum Perjanjian Syariah: Studi tentang Teori Akad dalam Ardi, Muhammad, “Asas-Asas Perjanjian (Akad), Hukum Kontrak Syariah , Dalam Penerapan Salam dan Istisna” Jurnal Hukum Diktum Vol.14 , Dalam Transaksi Syariah,” Jurnal Al- 'Adl Vol.II No.I, Januari 2018.

Dewi, Gemala, Hukum Perikatan Islam di Indonesia, Jakarta: Kencana, 2006.

Djamil, Fathurrahman Djamil, Penerapan Hukum Perjanjian dalam Transaksi di Faqih, Aunur Rohim, Bank Syariah, Kontrak Bisnis Syariah, \& Penyelesaian

Fikih Muamalat, Jakarta: PT RajaGrafindo Persada, 2007.

Hukum Kontrak Bisnis Syariah di UIN Sunan Kaljaga Yogyakarta, Hulaify, Akhmad, “Asas-Asas Kontrak (Akad) Dalam Hukum Syari’ah”, Jurnal Ilmiah Manajemen Vol. 3 No. 12019.

Islam di Indonesia, Jakarta: RajaGrafindo Persada. 2000.

Lembaga Keuangan Syariah, Jakarta: Sinar Grafika, 2012.

Manan, Abdul, Hukum Ekonomi Syariah, Jakarta: Kencana, 2014.

Muftadi, Dahrul, "Dasar-Dasar Hukum Perjanjian Syariah dan Penerapannya

Najati, Muhammad Utsman. Psikologi Qur'ani; Psikologi dalam Perspektif AlQur'an, terj. Amirussodiq, Solo: Aulia Press, 2007.

Otoman. "Pemikiran Politik Hasan Al-Bana dan Pembentukan Radikalisme Islam”, Jurnal Tamaddun, Vol. XV, No. 1, Januari-Juni 2015.

S. Burhanuddin S, Hukum Kontrak Syariah, Yogyakarta: BPFE, 2009. 
Al-Muamalat: Jurnal Hukum \& Ekonomi Syariah

Vol. 5 No. 1 Edisi. 1 hal. 48-67

P-ISSN 2460-5115|E-ISSN 2656-288X

DOI 10.32505/muamalat.v5i1.1519

Yasardin, Asas Kebebasan Berkontrak Syariah, Jakarta:Kencana, 2018. 